\title{
NJDRS \\ CDRD \\ Understanding Vikas: How Dalits Make Sense of Development in Rural Nepal
}

(i).

\author{
Sagar Shahi, PhD
}

Officer, Office of the Prime Minister and Council of Ministers, Singha Durbar, Kathmandu

Email for correspondence: sagar_shahi@hotmail.com

\begin{abstract}
The experiences, views and opinions of the marginalized people have generally not been included in the development discourse, even though they supposedly are the beneficiaries of development. Dalits are not only marginalized but also untouchable in the Hindu caste hierarchy. Notion of 'untouchability' labeled the Dalits unique characters in their identity from which other castes do not suffer. This study explores the Dalits' understanding on development. It shows that the meaning of development is contextual and Dalits understand it differently according to their age and educational background. Their understanding on development mostly refers to infrastructural, social, economic, human, cultural and political aspects of development. This study suggests a more culturally sensitive development practices that address/incorporate Dalits issues in a holistic way.
\end{abstract}

Key words: Vikas, development, caste, traditional values, Dalits, rural and social change.

\section{Background}

The term development implies a positive change or a movement from one state to a better one, which implicitly has better conditions (Gardner \& Lewis, 1996). Development is one of the common goals for any modern state in the modern world. Although there are different strategies, the goal of development remains similar. One of the goals of development is to uplift the underprivileged and marginalized communities. Development is about helping them, bringing them out of poverty, 'doing good' enabling them a decent life (Geiser, 2014). The voices or experiences of the marginalized people, however, are not considered important in the development process. It is now recognized that participation and ownership of the people are crucial to the success of development (Ukaga \& Afoaku, 2005). Though the majority of development visions are crafted internationally and nationally, it is the experience of the community members that is used to measure the success or failure of development in the end (Hutanuwatr \& Manivarna, 2005). Any initiative of development may result into failure unless it takes into account the interests of the local people. Eade (1997) mentions that examining the local peoples' understanding of development; including their views and feelings, helps in understanding the impact and effort of development on the individuals and community.

Nepal experimented different development approaches, most of which were borrowed from the West. However, in these foreign development approaches, the peoples' voices and experiences are not yet considered. Reasoning that many of these Western approaches have been criticized for their non-sustainability and cultural incompatibility (Khadka, 2007). Many literatures have been written about the process of development in Nepal. Some have seen development as rescuing the country from many ills whereas others have seen it as the carrier of many ills. Many writings about development are through the eyes of urban elites or foreigners. Although these 
studies provide insight into the experiences and lives of local people, they are often done through the eyes of outsiders and might have missed some of the deeper insights and experiences relevant to the discourse of development. To many researchers, the main source of information is the government and NGOs. As Chambers (1983) observes these information may provide only one perspective and may include the bias.

The current slogans of development is decentralization, empowerment of the marginalized, and sustainability. By understanding how the marginal people understands and experiences development can provide insight for those who are truly committed to empowering marginalized community. In case of Nepali Dalits the story is worse in comparison to other communities of Nepal. Development polices have advocated for empowerment, inclusion and development of the Dalits, and against caste-based discrimination and untouchability practices, and yet, the level of social exclusionary practices and socio-economic conditions of the Dalits have not been really improved in the context of Nepali society. Despite the some efforts by the Government of Nepal and NGOs/INGOs to uplift the socio-cultural and economic conditions of the Dalits over the last 60 years, Nepali Dalits are still the most disadvantaged group in social, economic and political platforms of Nepal (Dahal et al., 2002). The changes in the structure and system have not been able to diffuse widely in order to make a meaningful difference in the lives of the all Dalits. In a nutshell, the beginning of real change has yet to dawn for the Dalits of Nepal. In this contexts, this study tries to explain the Dalit's understanding of development based on their experiences by producing an insight into the Dalit's perspectives towards structural variables, including caste, economic situation, policy-practice and structure of the state.

\section{Dalits in Nepal}

The term Dalits is expressed extensively in diverse wisdom to its definition. The literal meaning of the word Dalit are shattered, over-burdened, suppressed, squeezed, stepped up, kneaded, ground down, shame by being required to bow to someone else's feet, or silenced through suppression (Nepal Academy, 2010). The modern definition of Dalits is different than its traditional and literal meaning. According to R. Tiwary the term Dalit refers to the group of communities, traditionally whose members have been socially backward, economically poor and politically weak (Tiwary, 2007). Similarly, Eleanor Zelliot defines Dalit as those individuals who have been broken and grounded by those above them in the social hierarchy in a deliberate and an active way. She further adds that, there is in the word itself and inherent denial of pollution, karma and justified caste hierarchy (Zelliot, 2001). Ghanashyam Shah proclaims "Dalits is not a caste, it is a symbol of change and revolution" (Shah, 2001). In the context of Nepal, National Dalits Commission defines 'Dalits' as "those communities who, by virtue of atrocities of caste-based discrimination and untouchability, are most backward in social, economic, educational, political and religious fields, and deprived of human dignity and social justice (NDC, 2008).

Kisan (2013) argues that the term 'Dalit' basically stands for four aspects in general i) social, cultural, economic and political deprivation, exploitation and exclusion ii) rejection of the concept of purity-pollution and caste-based hierarchy, iii) historically untouchables and discriminated iv) unity, change and revolution. Nevertheless, the ongoing debate attempt to define and analysis the term 'Dalit' on three distinct premises, class based analysis, communal analysis and caste-based analysis. The persons and institutions, whose analysis is based on class, argue that 
Dalits include the group of people who represent lower class in terms of economic, educational and political ability. BK (2009) argues that the meaning of Dalit has been constructed in two domins: political and social. For Dalit activists it is political. They use the term to claim equality and social justice and to gather the maximum number of votes. However, ordinary rural Dalits understand the term with reference to their low social or ritual status. For them, it is attached to the Hindu notion of a hierarchy of purity and pollution. Their daily lives are still largely shaped by caste and particularly by their ritual and economic relationships with the high castes. In Nepal, Dalits comprises of approximately 14 percent of the population (CBS, 2012). National Dalit Commission has listed 671 Dalits surnames belonging to 21 distinct Dalit sub-castes five in the hill Dalits category and sixteen in the Medhesi Dalits category. Although the highest concentrations of Hill Dalits are in the Mid-Western and Far-Western Regions and Madhesi Dalits are largely concentrated in the Central and Eastern regions, Dalits are scattered across Nepal. In some places, they have converted to other religion, but they have rarely been able to escape the stigma of their formal position in the Hindu caste hierarchy (Bennett et al., 2013). Dalits are not a homogenous group of people. In different region of Nepal, Dalits wear different dress code, celebrate different festivals, and, most importantly, speak different language.

Dalits face caste based discrimination as they are entrenched in an age-old caste system, often described as the 'iron chain' that reinforces hierarchy between what was once stratified as 'upper' and 'lower' castes in South Asia (Yekta, 2009). Dalits rank at the very bottom of this stratum. The details of discrimination against the Dalits speak of a stubborn stain in humanity. Even a Dalit's touch simply "destroys the sanctity and the usability" of the foods and water, rendering them unacceptable for others. An inter-caste marriage with a Dalit member is a completely prohibited as a 'stigma'. So much so that the Dalits are denied access to temples, private homes, festivities, restaurants, and public water sources, and hence, is segregated from the rest of society. They are least prioritized in the government services, health care and the financial market regarding loans. The society has thus been inhibiting their rights as citizens (Bhattachan et al., 2003). In addition, the Dalits still cope with various semi-bounded labour relationship, as reminiscence of a feudal legacy which obliges the Dalits to work for 'higher castes' through debt bondage (Adhikari, 2010). As Sen (2000) notes, in agrarian societies, land ownership is important for the access to employment, credit and education. In case of Nepali Dalits also landlessness has resulted in deprived economic conditions and low educational status of the Dalits, creating a vicious circle of a continued dependence on exploitative, often wage-less labour. Indeed, the Dalits in Nepal have been prevented from joining social, economic and political life on equal terms. The present position of the Dalits is known to be the most 'backward' and 'low' amongst the other communities in Nepal. The Dalits are economically poorest, educationally null-literate, socioculturally boycotted and excluded and politically powerless (Kisan, 2008). Dalit, there is no doubt, is still at the bottom of Nepali society that in terms of caste-based hierarchy, socio-economic class, access into decision making and implementing agencies, control over the resources, enjoying rights and opportunities of the State, power relation, human resource development, benefits of State's services and dignified life. Thus, the Dalits lag behind in their income and asset levels, in their education and other human development indicators.

Dalits are also considered the most socially excluded caste group of Nepal. T. Burchardt (1999), has identified five dimensions which he considers to represent the normal activities in 
which it is most important that individual participate. They are i) consumption activity (being able to consume at least up to some minimum level of goods and services considered normal for the society). ii) saving activity (accumulating savings, pension entitlements or owning property) iii) production activity (engaging in economically or socially valued activities like paid work, education, or training, retirement if over State pension age or looking after a family) iv) political activity (including voting, membership of political parties and of national or local campaigning groups and v) social activities (social interaction with family or friends and identifying with a cultural groups). Thus any groups are considered socially excluded if they are denied the opportunity of participation, whether they actually desire to participate or not. The groups of people who cannot gain that capacity are considered as socially excluded.

Data related to the different development indicators also show that the Dalits are lagging behind compared to the other communities of Nepal. The Dalits' poverty rate is 41 percent against the national average of 25.16 percent. The incidence of the Dalits poverty, while its prevalence has decreased in Nepal, still widespread among the Dalits. The literacy rate of the Dalits is 34 percent in contrast to the national average of 54 percent. Their life expectancy is 50.8 years as against the national average of 59 years. The mortality rate for less than five years is 90 per thousand, whereas the national average is 68 per thousands. Also, the per capita income of the Dalits is US $\$ 977$ per year, whereas the national average is US\$ 1597 per year, which is one of the lowest in the world. Furthermore, 23 percent of the Dalits are landless, while 48.7 percent have less than 0.1 hectares of land. For those who have land, cultivable land is less than 1 percent. The Human development Index (HDI) of the Dalits (0.424) is the lowest in Nepal and considerably lower than upper caste Bahun/Chhetri (0.552) and Newar (0.616) as well as of Janajati (0.494), the indigenous communities of Nepal whereas national average of HDI is (0.509) (UNDP, 2009; Kharel, 2010).

\section{Theoretical Perspectives}

There are triple alliance involved in most of the literature related to the modernization and dependency theory of development namely the theory, data and researcher (Bhattachan, 1993). However, participants have no place in such an alliance. In both theories, priority is given to theory and researcher. Theories are often imposed in accordance with the researcher's demand on participants who may or may not like it. Therefore, in most of the literature related to the modernization and dependency theory, it is clear what the researcher wants to say and do to participants, but it is rarely clear in the researcher's writing what the participants want to say and do. Both approaches show a clear sense of suppression on the voice of the participants. Cardoso and Faletto (1979) show their concern on this issue but make no effort to respect the participants' voice. Instead, they impose their own historical structural explanation of 'situation of dependency' in Latin America. Similarly, Evans (1979) says; "Most of Brazil's population are absent from this analysis because they are absent from the decision making that is being described." Neither modernization nor dependency theory is humble concerning with participants. The participant's voice should be given primacy and any theory of development should not be divorced from everyday realities of the people. Development theorists should heavily focus on the multiple voices of various groups of people, grasp the ideas and interest and communicate in a language intelligible to those being studied without any communication barriers in order to best serve the people's interest. 
The mainstream development theories have mostly focused on modernizing the sociocultural, political and economic life of the Dalits. The development in the sense of modernization process completely failed to improve the quality of life of the Dalits. The main reason behind this situation is the stigma of untouchability associated with the Dalits. In Nepal caste has become one of the crucial factors in development process. Conventional development theories mostly ignore such factor. Since, alternative development theories promote the values of inclusion, equity, human right, participation and sustainability (Griesgraber \& Gunter, 1996) such approaches would greatly help better to understand development in a caste-based society of Nepal. Bellah et al. (1985), argue that alternative development theories can ensure people's perspective of development in both the developed and developing countries. One of the advantages of these theories is that they rectify the related problems inherent in both modernization and dependency theories of development. Alternative development theories appreciate the peoples' voices and perceptions as the pulse of everyday as well as academic lives rather than as rhetoric. Mainstream development has a single, homogeneous thrust toward modernization and it underestimates people's diversity, complexity and adaptability. Alternative development theories on the other hand emphasize agency in the sense of people's capacity to promote social change (Pieterse, 1998). Alternative development is more anchored in people's subjectivity, rather than in overarching structure and institutions. These theoretical propositions helped to interpret the Dalits' understanding of development.

Some social scientists have realized the need for giving primacy to the voice of the participants in the development process and advocated some alternative theories of development. For instance Friere (1970) proposed a 'participatory learning process approach', Korten (1980) emphasized 'a learning process approach', Chambers (1983) demanded 'putting the last first', Korten and Klauss (1984) advocated 'people centered development', Cernea (1985) suggested 'putting people first', and Salmen (1987) has called on us to "listen to the people" all of which have advocated the voice of the participants. Clearly, the voice of the actual beneficiaries of development is the missing link in most theories of development. In various social scientific debates related with modernizing or developing the traditional or underdeveloped societies of the third world, the voices of the people shrink, unheard and do not get due attention.

\section{Research Questions}

- What are the occupational and social statuses of Dalits?

- How Dalits are understand the term development from their own perspectives?

\section{Research Design}

The study is designed under qualitative research approach. Under this approach, the ethnographic design was used as the methodology of this study because it allows to study Dalits in their usual village setting and to understand their everyday life and perceptions on their development process (Holloway, 1997; Neuman, 1994). Focus was given to appraise everyday life perspectives of Dalit community of Khalanga Village Development Committee (at present Malla Rani Rural Municipality) of Pyuthan. According to the census 2011, there are 249 Dalits households. The population of the Dalits is 1527, of them 811 being male and 716 female. There are three types of Dalit castes: Kami, Sarki and Damai. Among the Dalit population, 771 (50\%) are Kami, 590 (39\%) are Sarki, and 166 (11\%) are Damai. Every sect of Dalit community residing 
in Khalanga is identified by its own traditional occupation. The Kamis are expert in making utensils from iron, aluminum, and brass. They also make agricultural tools such as plows, sickles and the Khukuri - a typical Nepali knife. The Sunar is a sub-caste inside the Kami. They are skilled jewelry makers. The Damais are tailors and they also play Panchebaja, a set of typical Nepali musical instruments during marriage ceremonies. The Sarkis are the leather workers who specially produce and repair shoes. Further, the field work was conducted between June 2015 to November 2015. In order to have a comparative understanding on the Dalits' understanding on development, in-depth interviews with the twenty-seven Dalits from different age groups; including the elderly (above 60 years of age), the adults (above 40 and below 60) and the youngsters (below 40) from different gender, Dalits' sub-caste and ward numberwas conducted through purposive sampling.

\section{An Exploration: Elderly Dalits' Understanding of Development}

Most of the elderly Dalits found puzzled while sharing their understanding on development. However, most of them understood development simply means maintaining good networking of public service infrastructures. Such observation was common among the elderly Dalits who also claimed the witness to its historical development of the village infrastructure. My 78 years old male participant also saw the physical changes of the infrastructure and its outsourcing benefits to the whole residents as a reflection of development. Some of the elderly Dalits showed gratitude on the social impact of public facilities such as the health institutions, provision of education, clean and safe drinking water facilities and social security etc. Conversely, others are more concerned on the negative impact of development on its social and cultural values. My participants compare the present transportation facilities and condition of road with the past and express his satisfaction on this improvement as an indicator of development. In the past, the villagers' accessibility was at reach on foot trail. The village was almost isolated from the others. Destination to the nearby city was a five days walk with goods and items pottered on their back and shoulders. But now the situation is different. The bazaar (market place) area provides average transportation facilities that link the east-west highway on a paved road. The terminal bus service caters two journeys to the capital city and to other few cities. Bus and jeep further allow the exchange of goods and services to other rural bazaar areas of the district. At present, most of the elderly Dalits are satisfied with the widened road space for the pedestrians.

The elderly Dalits are aware in the importance of health and the role of health institutions as the provider of public health for the well-being of the community. Bal Bahadur Sunar (69) perceives the role of public health as one form of development in the village and its communities' lives. In the past, any incident of sickness was catered by the local healers. Epidemics were privately controlled by the ritual performance of the healers at the cost of animal sacrifice. But now the availability of various health facilities at the bazaar area in particular, such as one primary health centre, one ayurvedic health center and a few private clinics, have produced a more meaningful choices to good health and treatment. The local Dalits are found more attracted to modern treatment of western medicine. Compared to the past, the villagers now have long life expectancy and a low mortality rate. The elderly Dalits also see improvements in the communication sector as an indicator of development. The provision of electricity is a basic need for everyday life. Most of the Dalit settlements are scattered, distant from the bazaar area that the 
cost of installing electricity cable to their houses is costly. Most of them are residing nearby the bazaar use electricity but most of the Dalits are still using kerosene as fuel for lighting purposes.

The elderly Dalits showed their dissatisfaction over the electric power distribution in their village. Krishna BahadurSunar (67) expressed his dissatisfaction on the lacking of electricity available in his village in comparison with the dense distribution in the bazaar area for the past twenty years. Their situation is like batti muni koadhyaro (darkness beneath the light). Yet, he continues to hope for a 'brighter' community soon. The availability of clean drinking water is a matter of immense importance for healthy living conditions of the villagers in Khalanga. Unfortunately, in this village, the supply of safe drinking water is limited. Government and some NGOs have installed water taps in the Dalits community with irregular daily water supply. Due to this situation, the local Dalits still depend on the available natural water sources located at more than an hour walking distance to the village. Nar Bahadur Sunar (74) expressed his dissatisfaction in the sale of private water taps to the well-off Dalits by the Water Supply Committee while leaving the poor Dalit groups are thirsty. Huge amount of money are invested in the install of private taps in many houses of the well-off Dalits. Many of the elderly Dalits are not satisfied with this unfair distribution system.

Education is a major indicator of development. Now there are a number of educational institutions established in Khalanga VDC. However, all of these learning institutions are located in non-Dalit settlements. Bhakta Bahadur Nepali (75), compared the historical development of the education condition of the Dalits community of the past with the present. He perceived that free access to education as a form of development. In the past, there was no public learning institution available in the VDC. A primary school was established in the bazaar area in 1950s exclusively for non-Dalits. But now all wards of the VDC are facilitated with public schools where the acceptance of Dalits' children into the learning institution are available up to Bachelor's level. For the Dalits, scholarships are provided upto primary level with the unnecessary pay of school fee upto the tenth grade. Similarly, the intermediate and bachelor level are also supplied with scholarship by some organizations. Most of the district level government offices and other organizations such as different NGOs/INGOs are located in the bazaar area. The strategic location invites more residents into the VDC to occupy the benefits of getting government services than in other VDCs of the district. Basic government services and other organizations would take few working days where the clients from other VDCs need to spend few days in the headquarter Khalanga bazaar. Unlike others, as for the Dalits of Khalanga, the short walking distance to the bazaar is an advantage.

However, many of them are unaware of the facilities disseminated from the government and other organizations. Amar Bahadur Nepali (73) explained the previous lacking of state representation and other organization in the village to provide public services and facilities. Now, the local Dalits can enjoy opportunities and benefits such as senior citizenship allowance within one day in the VDC office. He further expressed unfavourable perception on its assimilation concept of development and prefers it to run on the ground of traditional values in the midst of modernity. As he describes the present situation like a wrong tune to the right song. He agrees to progressive development to take place in his home village while simultaneously warns the generation of traditional loss in the values as the basis to their happiness. The elderly Dalits further described the impact of development on the changes in their core values. They described the younger generation as 'being ignorance' to their collective value that unlike the present generation,

Nepalese Journal of Development and Rural Studies, 14 (1\&2), 2017 
the elderly generations are more collective and community oriented for the commitment on the shared community activities. In the past, collective participation in the local activities was made accountable for services such as building infrastructure, protecting the environment, and protecting local resources. In time of crisis, the community members collectively shared views and opinions on uprising issues. Individual knowledge was recognized with skills and experience valued collectively by the community.

Most of this group categorized development as infrastructural activities. The construction of road, electricity, health post, school building, communication, drinking water taps are understood as infrastructural development. The elderly Dalits have seen it, benefited from it, and understood it in a taken-for-granted manner. Together with the infrastructural development, they understood that social progress such as the provision of education, health services, drinking water facilities and social security services come as part and parcel of the development. The prescribed formula of the state is viewed as 'foreign' western concept by many of the elderly Dalits and relates their concern with the community's depleting values both culturally and traditionally. With this impact, this group assumes the creation of individualistic and selfish character in the younger generations despite the unclear understanding on the meaning of development. The claims on development conducted on the ground of traditional knowledge, skill and local resources emerged with the rising conflict of modernity. The truth lies on the recognition for inventing traditions as development agency.

\section{Adult Dalits' Understanding of Development}

I repeated the same question to the adult Dalits in order to find out how development is understood. In comparison with the elderly Dalits, development is taken as an indicator of progress to modernity. Some of the adult Dalits won high recognition for their involvement in the community development. Many also relate some of the community changes with the mobility of local Dalits without offering support from the government and other organizations. In the view of adult Dalits, economic activities are limited mainly to their caste-based traditional occupations. Many occupy as manual labours in the bazaar area, serving the high castes group in return for food grains. Some of them put additional effort to farm on a small-scale. Yet, poverty, hunger, diseases, illiteracy, and unemployment persist. Their lives remain harsh and difficult. Majority of the Dalits' households hardly have their daily meals for five to six months.

Piety as the rule of the day, the local Dalits blames their fate for being poor and untouchable. Thus they remain silence with critics on the government and high castes people. As a form of escapism, many of the adult Dalits decided to migrate to India for job opportunities such as police, army, watchman, labour and so on. Some joined the defense in national service such as the police and army. In general speaking, migration provides greater access to opportunities as well as experiences outside the local community. These adult Dalits understood the ongoing development activities in other societies and tried to implement it to their own Dalits' communities, integrating both cultural and social practices. Being the real development participants of their village, the adult Dalits demanded a suitable form of development for their own community. The adult Dalits implemented new knowledge and skills in the replace of traditions such as the use of latrines, water pipes and zinc roof (corrugated iron). Other than physical contingencies, they also brought some new 'awareness' into the community such as 
personal hygiene, sanitation of the settlements, and education. According to them, the newly transmitted values were easily accepted by the community and have gained support from the villagers who were also engaged in traditional occupations.

According to the Maheshwar Nepali (60), a retiree from India, and at present working for the social welfare of the Dalits described some features of development that are taking place in the Dalits community. He explained the infrastructural development such as road, an electricity, water tap and communication are less vigorous in comparison with the past. In the economic sector, the Dalits now diversify from their traditional caste-based occupations to more causal activities such as small grocery shops, public services and so on. The opening of Gulf countries further invites more Dalit youths for better opportunites. Remittance flourished to the families back home. New knowledge and education programs form new attitude and behavior among the local Dalits. This shows some improvements in the human development indicators. In general speaking, the Dalits community and local Dalits are more prosperous today than they were before.

Generally, all adult Dalits are aware of the minimum development achieved in the village. However, this group also deny that improvement in infrastructure and a changing pattern of attitude and behaviour complete the development process in the village. The adult Dalits persistently expressed their disatissfaction with the pace of development being practiced by the participants. Some Dalit settlers are noted using certain facilities such as the road, mobile phone, market, schools, health centers only because they live nearby the non-Dalits of Khalanga bazaar while others are still found lacking of basic facilities such as electricity, water supply, proper roads and other institutions. This is only the trickle down effect of the development. Raj Kumar Nepali (48), described Dalits' settlements as underdeveloped, deprived, lagged behind and trapped in the web of poverty with high level of unemployment and social discrimination. For Raj Kumar Nepali, Vikas, a local word for development, is identified as a Nikas (a vent) to the poverty, uneployment, caste-based discrimination and untouchability, ill-health, illiteracy and to all kinds of physical and social hardship. The poverty, unemployment and discrimination are the three barriers for solutions to vikas in the village and community.

The adult Dalits expressed more openly towards any cultural changes in the field of modernization. They emphasized on incorporating western values and ideas into their traditional development practices in order to keep the cultural value intact. Many of this group regards western knowledge a conduct of modern structure on the society. The adult Dalits noted that this is a continuing dilemma by the elderly Dalits. To them it is a question of narrowing the distance of understanding development among them. Many in the adult group grappled with the question of how to have both without sacrificing the other. Raju Pariyar (52) a retired police officer vividly pictures the traditional life as peaceful and harmonious between the rich and poor, young and old. Social difference was less visible with the living practice of core values such as cooperation and unity, particularly in the economic field of production where idle lands were cleared collectively by anyone at nil cost. In general, they wore the same simple attire without a single praise to 'keep up with the Joneses' attitude at its premium. He noted the changing pattern of attitude among the poor 'to dress up well even before Dashain'. He further compares today's situation as 'likely' resembles the hakims (people of importance).

According to the adult Dalits, sociality in the past was much stronger than today. The spirit for co-operation among the Dalits community was greatly felt in community development 
activities such as constructing road, digging canal and installing water pipes. Their full participation has reduced certain dependence on the government and other outside bodies. Some adult Dalits think of this as 'unlikely' where the condition of the present situation with its dependence has dominantly taken over the spirit for cooperation. According to the adult Dalits, the younger Dalits are decisively manipulated by modernization that has claimed the loss of some core values. Santa Pariyar (55) commented that Dalits should not be more dependent on the outsiders such as government and NGOs which he also claimed a paralytic prescription to 'undeveloped, lazy and dull' Dalits. To him, the imaginary Dalits is an active and creative Dalits and a tribute to the local development activities in the community.

\section{Younger Dalits' Understanding of Development}

Most of the younger Dalits are engaged in different kinds of jobs in different parts of Nepal, India and aboard. Yet, some Dalit youths remain occupied in caste-based traditional occupations. There are groups of uneducated and unemployed Dalit youths who temporarily add to labour pool in the bazaar area. The educated ones are more interested in Dalits activism, occupying jobs in Dalits' development issues. Jobs in the government sector such as the police and the army are considered better. Yet, during my field work, none of the Dalit youths are found working in the civil service. Many of the Dalit youths join higher education institution at the intermediate and bachelor level. The level of experience and education of the Dalit youths is an indicator to their understanding on development. Jeevan Pariyar (32) working in South Korea, expressed his views on development on the ground of his experience, in comparison with development achieved in Korea. He listed out components of physical development found in Korea such as big mall, metro train, facilities of electricity with no power-cut (load shedding), 24 hours water facilities, free health and education facilities, industry and technology and compared with those available back home in Dalit community of Khalanga that he resembled as trapped in the medieval age. Jeevan defined development on the basis of his personal observation and experiences in the developed world. He simply concluded that the Dalits' community is still underdeveloped and primitive stage, as the local proverb says "frogs in the dark well.

In contrast, Rom Bahadur Nepali (37) runs his daily livelihood on caste-based traditional occupation perceived a different view on development. In his understanding, development in the Dalits' community should not be measured by the standard of infrastructural development but instead by the needs to relate it with the preservation of identity such as the Dalits' traditional job occupations. He explained that connectivity to development by its traditional occupation produces a vivid picture of meaningful identity that generates a better benefit than it does on infrastructure. This he claimed as the determining factor in the Dalits traditional development process. The loss of its traditional job occupations also lead to the loss of identity. Rom Bahadur Nepali believes that every Dalit should show some pride and dignity while preserving this identity in order to maintain the meaning of development. Like Rom Bahadur Nepali, Gita Nepali (22) a college student at 3rd year bachelor level and working as a community mobilizer in a local NGO, Malla Rani Rural Development Concerned Center (MRDCC), also has a different view on development. Gita acquired some experience in her working commitment with her own Dalits community. As a close observer to the issues of development among the Dalits community, she explained development as a state of 'no-caste based discrimination', 'no untouchability', 'no differentiation' and 'no 
humiliation'. By prioritizing self-respect and dignity, none to her belief should be without development. She denies that improvement in the infrastructure such as roads, bridges, power lines and other physical facilities provides a closer meaning to development. Previously, development was exclusively equated with GDP and economic growth. But, today development is measured in terms of its human development index. Since development remains a very complex phenomenon, indexes and numbers cannot precisely capture its human inherent complexities. A PhD holder with good income will still remain as the untouchable before the non-Dalits who are entitled for social, economic and political freedom and at which the Dalits, on the other hand, are not entirely free to their own jurisdiction. To Gita, being a marginal class citizen often invites the target of violence and humiliations from non-Dalits. Thus dignity, human rights and social justice are often prioritized as the Dalits' political ethics in implementing development process. To Gita, without understanding on development, no mechanical measure of human complexities would be reached.

In many interviews, most of the elders and adult Dalits mentioned that the current process of development is changing their cultural values and traditional skills. The Dalit youths are not without this awareness and explained the changes as necessary with the changing situation. Unlike the elderly Dalits, the Dalit youths seek to openly adapt the good practices and leave some of the irrelevant traditional practices of the Dalits such as the consume of carcass and the confined to caste hierarchy system among themselves. Furthermore, these groups all seem to agree that development should not be seen as a tool to eradicate Dalits' cultural values but instead as a measure of cultural relevance in the midst of development. One Dalits youth Lokendra Sunar (22) emphasized the need for development and the call for participants from the villagers. Modernity, he added, should be accepted as much important partly from its useful benefits of facilities. To Lokendra Sunar, the pride and dignity for identity fulfills most of the development needs.

More professional views on development are presented by some of the younger Dalit activists. This group believes that development is closely related with empowerment, social equality, equity, social justice, social integration and social inclusion. The Dalits are generally described as backward that calls for some extra effort to change. The socio-economically and politically disadvantaged Dalit society, in general, seek for more rights and support from government, NGOs and especially from non-Dalits in order to fit the needs and identity into the mainstream of the larger society. Their awareness on inclusion is now a key factor for good governance. Menuka Sunar (28), one of the Dalit activists said that they have been lagging behind socially, economically, and politically for a long time. The high caste people have adopted a policy of caste discrimination, injustice and oppression against us and have been keeping us in isolation from the social affairs, from participating in state resources, policy formulation, implementation of which is still intact even today. Settlements of Dalits have not shown any changes.

\section{Conclusion}

Understanding of Dalits on development is influenced by the context, age groups, existing available facilities, economic condition and level of education. Generally, for the local Dalits , the notion of 'development' has become a parcel of physical, economic, social, cultural, and political progress but the meanings it carries and refers are multiple, diverse, overlapping and contradictory also. This implies that the understanding of development is contextual and yet to be universally defined. In the context of Nepal, from the beginning, the state development activities 
were influenced by the modernization theories and state gave priority to physical infrastructure and economic development activities. The local Dalits especially from the elderly and adult generation watched all this happening and began to understand "development" as synonymous to such activities. On the other hand, alternative development discourse brought some remarkable and significant new concepts in understanding the people's meaning on development from various manners. Dalits' understanding on development has shifted toward the alternative development discourse from the mainstream development discourse. The younger Dalits' understanding of development is not limited on physical, economic and social development activities and they understand development as a process of holistic development of an individual and society. All in all, most development literature are top-down and hegemonic but this study show a possibility on how to incorporate local marginalized and untouchable people into the mainstream of development discourse. The findings of this study further reinforces the possibility of envisaging an alternative development discourse that empowers rural people and increases the possibility of ensuring sustainable development discourse.

\section{References}

Adhikari, J. (2010). Access to Land and Social Inclusion in the Context of High Mobility in Nepal.

In K. Stokke \& M. D. Manandhar (Eds.), State and Society: Social Exclusion and Inclusion in Nepal (pp. 91-130). Kathmandu: Mandela Books Point.

Bellah, R. N., Madsen, R., Sullivan, W. M., Swidler, A. \& Tipton, S. M. (1985). Habits of the Heart: Individualism and Commitment in American Life. Berkely: University of California Press.

Bennett, L., Sijapati, B. \& Thapa, D. (2013). Gender and Social Exclusion in Nepal Update. Kathamandu, Nepal: Himal Books.

Bhattachan, K. B. (1993). Public Debate on Development: Sociological Perspectives on the Public Philosophy of the Development of Nepal, [Unpublished doctoral dissertation]. Submitted to University of California. Berkeley.

Bhattachan, K. B., Hemchuri, K., Gurung, Y. B. \& Bishwokarma, C. M. (2003). Existing Practices of Caste-Based Untouchability and Strategy for a Campaign for its Elimination. Kathmandu: Action Aid Nepal.

BK, A. (2013). The Stigma of the Name: The Making and Remaking of Dalit Identity in Nepal. Kathmandu: Social Science Baha.

Cardoso, F. H. \& Falleto, E. (1979). Dependency and Development in Latin America. Berkeley: University of California Press.

Central Bureau of Statistics (CBS). (2001). The Population Census of Nepal, 2001. Kathmandu: CBS.

Central Bureau of Statistics (CBS). (2012). The Population Census of Nepal, 2011. Kathmandu: CBS.

Cernea, M. M. (Ed.). (1985). Putting People First. Sociological Variables in Rural Development. New York: Oxford University Press.

Chambers, R. (1983). Rural Development: Putting the Last First. New York: Longman. 
Dahal, D. R., Gurung Y. B., Acharya, B., Himchuri, K. \& Swarnakar, D. (2002). National Dalit Strategy Report Part 1 Situation Analysis of Dalit in Nepal. Kathmandu: National Planning Commission.

Eade, D. (1997). Capacity-Building, An Approach to People-Centred Development. Oxford: Oxfam.

Evans, P. (1979). Dependent Development: The Alliance of Multinational, State and Local Capital in Brazil. Princeton: Princeton University Press.

Freire, P. (1970). Pedagogy of the Oppressed. New York: Seaburg Press.

Gardner, K. \& Lewis D. (1996). Anthropology, Development and the Post-Modern Challenge. London: Pluto Press.

Geiser, U. (2014). Conceptualizing 'Contested Development' From Grand Narratives to the Nittygritty of the Everyday. In: S. R. Sharma, B. R. Upreti, P. Manandhar \& M. Sapakota (Eds.), Contested Development in Nepal: Experiences and Reflections. (pp. 1-25). Kathmandu: School of Arts, Kathmandu University and Nepal Centre of Contemporary Research.

Griesgraber, M. J. \& Gunter, B. G.(Eds.). (1996). Development: New Paradigms and Principles for the 21st Century. London: Pluto.

Holloway, I. (1997). Basic Concepts for Qualitative Research. London: Backwell Science Inc.

Hutanuwatr, P. \& Manivannam, R. (Eds.). (2005). The Asian Future: Dialogue for Change Vol. 1. New York: Zed Books.

Khadka, (2007). Understanding Dalits of Nepal from Different Lenses: A Socio-cultural Study. Kathmandu: Social Inclusion Research Fund (SIRF).

Kharel, S. (2010). The Dialectics of Identity and Resistance among Dalits in Nepal, [Unpublished Doctoral Dissertation]. Submitted to University of Pittsburgh. Pittsburgh.

Kisan, Y. B. (2008). A Study of Dalits' Inclusion in Nepali State Governance. Kathmandu: Social Inclusion Research Fund (SIRF).

Kisan, Y. B. (2013). Dalits' Inclusion in Nepali State: Prospects and Challenges, [Unpublished Doctoral Dissertation]. Submitted to Tribhuvan University. Kathmandu.

Korten, D. \& Klauss, R. (Eds.). (1984). People Centered Development; Contributions Toward Theory and Planning Frameworks. Connecticut: Kumarian Press.

Korten, D. (1980). Community Organization and Rural Development: A Learning Process Approach. Public Administration Review, 40 (5), 480-511.

National Dalits Commission (NDC) (2008). Proposed Bill of National Dalit Rights Commission. Kathmandu: NDC.

Nepal Academy (2010). Nepali BrihatSabdakosh (7th ed.). Kathmandu: Royal Nepal Academy.

Neuman, W. L. (1994). Social Research Methods: Qualitative and Quantitative Approaches (2nd ed.). Massuchussentts: Allyn and Bacon.

Pieterse, J. N. (1998). My Paradigm or Yours? Alternative Development, Post-Development, Reflexive Development. Development and Change 29, 343-373.

Salmen, L. F. (1987). Listen to the People. Participant-Observer Evaluation of Developing Projects. New York: Oxford University Press.

Sen, A. (2000). Social Exclusion: Concept, Application, and Scrutiny, Social Development Paper No 1, June. Bangkok: Asian Development Bank.

Nepalese Journal of Development and Rural Studies, 14 (1\&2), 2017 
Shah, G. (2001). Introduction: Dalits Politics. In: Shah, G. (ed.). Dalit Identity and Politics. Vol. 2, pp. 17-43. New Delhi: Sage Publication.

Tiwary, S. J. (2007). Dalits' Access to Water: Patterns of Deprivation and Discrimination. International Journal of Rural Management. 3 (1), 43-67.

T. Burchardt, L. G. (1999). Social Exclusion in Britain 1991-1995. Social Policy and Administration. 33 (3), 227-244.

Ugaka, O. \& Afoaku, O. G. (Eds.), (2005). Sustainable Development in Africa: Multifaceted Challenges. Asmara, Eritrea: Africa World Press.

United Nations Development Programme (UNDP). (2009). Nepal Human Development Report 2009: State Transformation and Human Development. Kathmandu: UNDP.

Yekta, S. (2009). Caste System in India: A Historic Perspective. New Delhi: Palpaz Publication.

Zelliot, E. (2001). From Untouchable to Dalit: Essays on Ambedkar Movement. New Delhi: Manohar Publishers and Distributors. 